カルボキシメチル基在含有するビスコースレーヨンの研究 興国人絹パルプ株式会社 是松幹雄

\title{
STUDIES ON VISCOSE RAYON CONTAINNING CARBOXYMETHYL RESIDUE
}

\author{
By Mikio Korematsu
}

(Research Dept., Kokoku Rayon and Pulp Co., Saeki, Oita Prefecture, Japan)

Alkali cellulose was treated with sodium monochloroacetate in Werner, shredder and ageing vessel. After xanthation, it was dissolved and spun by normal process, and there were no apparent difficulties. $\gamma$-value of carboxymethylated alkali cellulose was lower than in the normal one, but it can be dissolved easily by caustic soda.

Viscose rayon containing carboxymethyl residue has a few different mechanical properties from normal, but its $\mathrm{Cu}, \mathrm{Hg}$, and $\mathrm{Al}$ salts are resistant to fungi and have high wet strength.

(Received June 16, 1959)

\section{1. 緒言}

Daul, Reinhardt, Reidは木綿織布をもノクロール醡 酸の水溶液に浴せき，王さくし，つぎに濃厚アルカリ乐 溶液に漫せき，正さく，水洗子ることによつてカルボキ

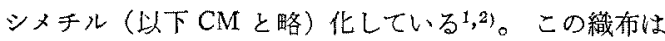

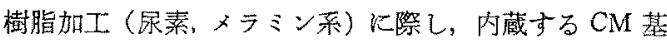
が酸㤬螌媒として作用し，樹脂液に触媒索加光る必要が なくなるばかりでなく，酎菌性と永久糊付けの效果とを 持つているといわ机る。

著者は同法に徒つて，ビスコース・レーヨンステープ

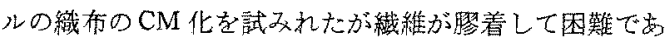
つた。めらかじめCM 化した擮維素を普通のビスコ一ス と類似の力浩で, 硫化, 溶解, 紡苏することがでされば,

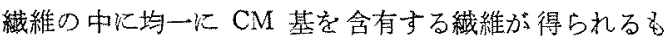
のと予想され，Daul などの木綿繊布と同嵄の效果が期

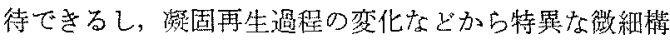
造を持ち，変つた機珹的性筫を持つのではないかこ考え て本研究を行なつた。

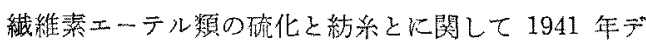
ユポン社が米国特許を得ているが3)，との詳緗の報告は ないよ5なので，製造過程を検討した結果の概要と得ら

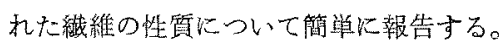

\section{2. 実 験 万 法}

\section{2,1. C M 化}

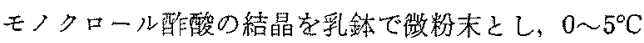

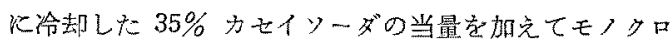
一ル酿酸ソーダのペーストを作つて扰く(中和熱によつ
て㫒温するとグリコール䣫酸になるおそれがあるので， 冷却しながら注意して調製する必要がある。また毎回所 要量を作る)。レーヨンパルプを18\%カセイソーダに浸 せき，王さくして得たアルカリセルャ一スをウェルナー 型粉砕機の中で 30 分間粉䂗し，更に粉啸を続けながら前 記のモノクロール酢酸ソーダのペーストを 5 ないし 10 分間にわたつて均一に加学る。そのまま粉破混合を続け 総計 60 分間粉砕を行なつて取り出し，引き続き老成と $\mathrm{CM}$ 化とを同時に進行させる。

\section{2. 硫化, 溶解, 紡系, 精練}

通常のアルカリセルトースとほ济同様に硫化, 溶解,

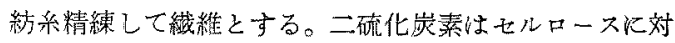
して 40\% 双は 30\% 重量使用し，ビスコ一ス組成は七

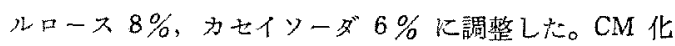
に際してモノクロール酷酸ソーがと当量のアルカリが消 䩀されるのて調整に注意しなければならない。

実験は 1 ハッッチ当りパルプ $5 \mathrm{~kg}$ 代迤みの中実験プラ ント使用した。

\section{3. 分析法之試験法}

CM 化置撸度の分析

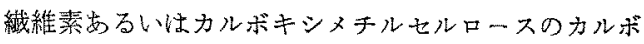

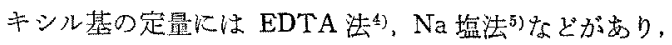

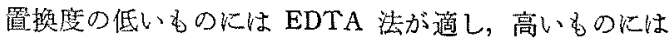
$\mathrm{Na}$ 塩法が適しているといわれる。本研究が得た代表的 な数種の試料について EDTA 法と，以下に述べる逆滴定 法とを比輘したところ，良好に一致したので本研究では 簡便のためすへて逆滴定法を採用した。

約 $1 \mathrm{~g}$ の試料学グラスフィルター (G-3)に採り, N/10 塩酸で洗浄し次に蒸留水で洗浄する。充分洗浄した試料 
を恒量まで乾燥し，精科後に共栓三角フラスコに移す。 これに蒸留水 $50 \mathrm{cc}$ と $\mathrm{N} / 10$ カセイソーダー $5 \mathrm{cc}$ とを 入れ，密栓してよく振り，穻温で 12 時間以上放置する。 フェノールフタレインを指示楽として N/10 塩酸を中和 点上り約 $0.1 \mathrm{cc}$ 過剩に加えてから $40 \sim 60^{\circ} \mathrm{C}$ に加温し, 充分かくはんしつつ，N/10カ七イッーダで滴定する。

CM 化しない点だけが異る同種の試料について上と同 様に行ない, オキシセルロースのカルボキシル基を求め て，その差を CM 基とし，七ル口一スの基本分子 100 個 当りの犆換基の数老置換度（以下D.S. と略）とした。

ビスコース試験と糸質試験

組成， $\gamma$ 洒，熟成度，粘度，Kw などのビスコース試

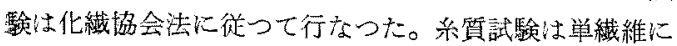
ついて張強伸度, 湿涅強伸度, 結節強伸度, 港縮試験 などをJIS 䏇準法で行なつた。

\section{沃度吸着量試験}

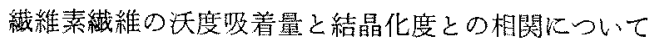
Schwertassek $^{6}$ によつて提唱され, Hessler, Power に よつて改衰された7\%。本研究では Hesslerに従つて測定 し，吸着された沃度のモル数をセルロースの100基本分 子当りに計算して比較した。

埋没試験

CM 化されたビスコースレーヨンスフ长効象と共に土 中(赤土の多い烟) に埋没して 2 ケ月徭见夻の残留强伸 度を测定して耐菌性の比較を行なつた。CM 基杼予名 種の金属イオンを交換させておき，塩の種類による影䁹 を見た。

\section{3. 実験結果上考察}

\section{1. アルカリセルロースの CM 化}

第 1 图は $18^{\circ} \mathrm{C}, 25^{\circ} \mathrm{C}$ および $35^{\circ} \mathrm{C}$ の $\mathrm{CM}$ 化反応の進 行を示している。第2龱にはモノクロール酢酸ソーダの 使用量党增加与ることに上つて，CM 化置換度 (D.S.) とモノクロール唒酸》一ダの反度率とがどのよ5に变化 方るか示した。これらから明らかなよ5に，アルカり せルロース比較的容易に CM 化されるが，モノクロ

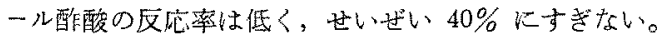
多舅にモノクロール酶酸ソーダを使うとか学つて D. S. 怟下寸るが，これ性 CM 化の不均一に基つくく溶解損 失（分析前の精製）に起因してふり，精製にメタノール を使用した場合は，このような低下は認められない。害 用的な CM 化置換度としては 4 付近が限界である万。

$\mathrm{CM}$ 化剂之して専らモノクロール酿酸りーダのペース 卜を用いたが，これは第1表に1例を示すように遊離酸 を用いたり，古いは過㮃の $\mathrm{NaOH}$ を含むモノクロー ル酢酸ソーダを用いるとよい結果が得られなかつたから

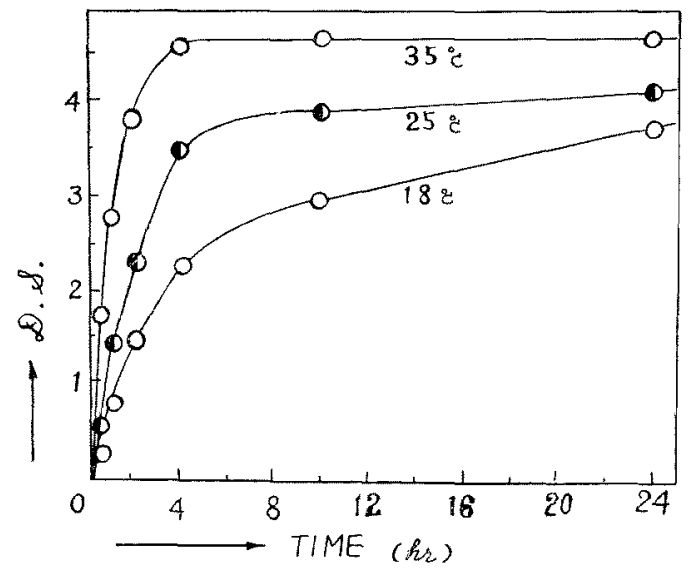

Fig. 1. The effects of time and temperature on degree of substitution (mol/100 glucose units)

$18 \mathrm{~mol}$ of sodium monochloroacetate were added to 100 glucose units of alkali cellulose.

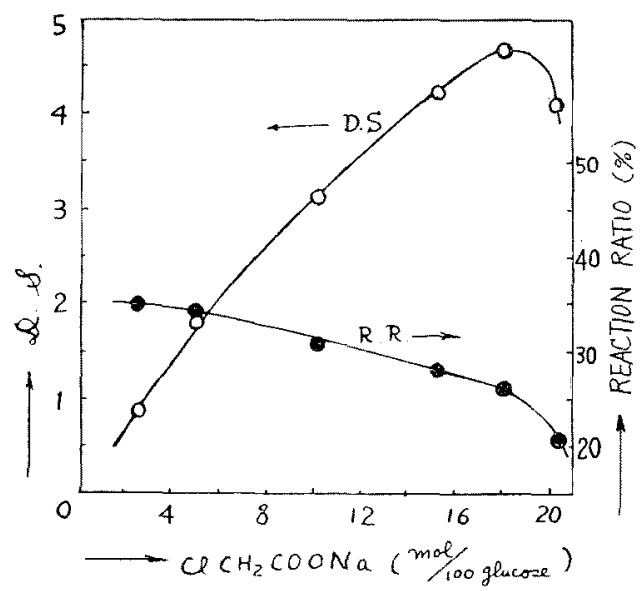

Fig. 2. Relation of D.S. and reaction ratio to amounts of sodium monochloroacetate used. $\left(35^{\circ} \mathrm{C}, 24 \mathrm{hr}\right.$.)

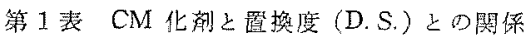
反応温度 $35^{\circ} \mathrm{C}$, 反応時間 24 墔間

\begin{tabular}{c|c|c} 
添加量 $\mathrm{mol} / 100$ & 100 \\
$\mathrm{CM}$ 化 剂 & 5.08 & 10.16 \\
\hline $\mathrm{ClCH}_{2} \mathrm{COOH}$ & 1.81 & 2.74 \\
$\mathrm{ClCH}_{2} \mathrm{COONa}$ & 1.83 & 3.10 \\
同上と更に当量の $\mathrm{NaOH}$ & 0.02 & 0.42 \\
\hline
\end{tabular}

である。

游離酸の場合には使用量が增すにつれて定性的ではか るが不均一さの增加が羿められ，アルせル中の $\mathrm{NaOH}$ も甚しく低下するため硫化工程の障害も增加した。過剩 


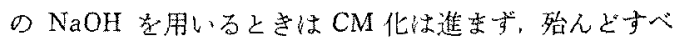
ての $\mathrm{ClCH}_{2} \mathrm{COONa}_{2}$ 加水分解してダリコール酷酸に なつてし类らものと思到れ。

\subsection{CM 化アルセルの硫化, 溶解, 熱成}

$\mathrm{CM}$ 化されたアルカリ七ルロ一大を硫化溶解して普通 ビスコースと比校した結果を第 3 図上第2表とに示し to

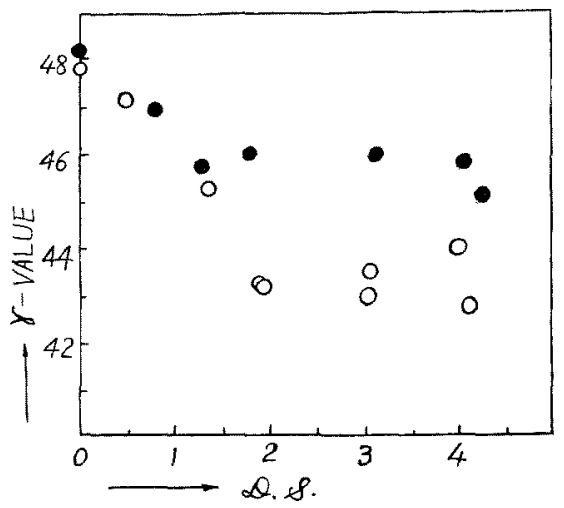

Fig. 3. Correlation between D.S. and $\gamma$-value, $2 \mathrm{hrs}$. after dissolving the cellulose into $\mathrm{CS}_{2}$ $38 \%(\bigcirc)$ and $40 \%$

第 2 表 $\mathrm{CM}$ 化アルせルの硫化溶解に上るビスコース

\begin{tabular}{|c|c|c|c|c|c|c|c|}
\hline \multicolumn{2}{|c|}{ アル七ル分析值 } & \multicolumn{6}{|c|}{ ビスコース分析值 } \\
\hline \multirow{2}{*}{$\begin{array}{l}\text { カルボ平 } \\
\text { シル基 } \\
\mathrm{mmol} / \mathrm{gr}\end{array}$} & \multirow{2}{*}{ D. S. } & \multirow{2}{*}{$\mid \begin{array}{l}2 \\
a-x\end{array}$} & \multirow{2}{*}{$\begin{array}{l}T ル 2 \\
\text { カy }\end{array}$} & \multirow{2}{*}{$\gamma$ 洒 } & \multirow{2}{*}{ Kw } & \multicolumn{2}{|c|}{ 米分散䋐系 } \\
\hline & & & & & & $F_{1}$ & $\mathrm{~F}_{2}$ \\
\hline 0.052 & 対照 & 8. 28 & 6.13 & 47.9 & 167 & 330 & 990 \\
\hline 0.065 & 対照 & 8.09 & 5.99 & 48.3 & 209 & 440 & 988 \\
\hline 0.030 & $\begin{array}{l}I \text { 场 ビ } \\
ス z-ス\end{array}$ & 8.17 & 5. 67 & - & 434 & 208 & 704 \\
\hline 0.171 & 1.84 & 8.08 & 6.07 & 46.0 & 166 & 385 & 660 \\
\hline 0.172 & 1. 86 & 8.16 & 5.99 & 43.4 & 205 & 224 & 648 \\
\hline 0.172 & 1.86 & 8.11 & 5.99 & 43.3 & 118 & 352 & 684 \\
\hline & & 8.00 & 6.04 & 46.3 & 200 & 440 & 704 \\
\hline 0.242 & 3. 02 & 8.04 & 5. 97 & 43.5 & 133 & 396 & 748 \\
\hline 0.240 & 2.98 & 8. 30 & 6.04 & 43.0 & 135 & 364 & 812 \\
\hline 0.317 & 4. 25 & 8.03 & 6.05 & 45. 2 & 257 & 316 & 902 \\
\hline 0.308 & 4. 12 & 8.30 & 6.02 & 45.9 & 166 & 396 & 748 \\
\hline
\end{tabular}

CM 化の進行にとるなつて硫化度は低下寸る傾问它持 つている(第3园炕2系列以ついて行なつた結果を示

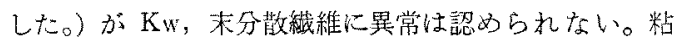
度の时間以上る変化、ホッテンロート数の变化も調べた。 粘度变化は﨎照と相違はないが，ホッデンロート数は対 照に比較して高く，しかも時間による減少が小さい。こ れはCM基によつてアルカリへの溶解性が高められてい るからである5。
なお，普通のビスコースにモノクロール酸酸ソーダを 添加混合乙熟成と同特にCM基を導入することを試みた がせルロースザンテートになつているためか，ビスコー ス性繰色在星してダル化した。再生後にカルポキシル基 を测つたが，CM 化は起つていない。

\section{3. 紡系}

凝国雪生精練の過程で一部の CM 化された織維素妘凝 固浴，精練浴に溶解損失することが考光られる。第 3 表 に種々の程度にCM化したアルセルを硫化溶解した後に

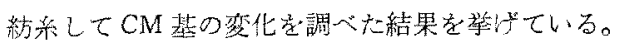

\begin{tabular}{|c|c|c|}
\hline 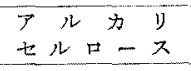 & 再生緎維溸 & 両者の差遑 \\
\hline 1.92 & 2.88 & -0.91 \\
\hline 2.86 & 4.00 & -1.14 \\
\hline 4. 16 & 5.48 & -1.32 \\
\hline $0.22_{6}$ (对照)* & $0.22_{6} *$ & $0.00_{2} *$ \\
\hline
\end{tabular}

㠜固浴組成：硫酸 $120 \mathrm{~g} / \mathrm{l}$, 硫酸西鉛 $14 \mathrm{~g} / \mathrm{l}$, 硫酸ナトリウム $350 \mathrm{~g} / \mathrm{l}$, 浴温度 $50^{\circ} \mathrm{C}$

*対照の双はカルボル基含量 $\mathrm{mmol} / \mathrm{g}$ で ら敞した。

予想に反して紡出織維のおが高い．D.S．を持ち，その， 增加量も D.S.の高いアルセルの方が著しい。これは前 にも述べたよらにCM化が不均一なたる，アルセルの表 尿が水溶性を呈するまでに部分的に高度にCM 化され， 精整損头が大きいのに対し, 硫化溶解されてから紡出さ れた場合には CM 基が全体に均一に分散しているたるに 溶解損失する緸が少いと考兄られる。

一錘式の中実験プラント紡糸機（各部分の様式寸法忙 工場現場と大差ない）用いて $1.5 \mathrm{~d}$ (レギュラー), $2.5 \mathrm{~d}, 3 \mathrm{~d}, 10 \mathrm{~d}$ (クリンプ) 作つた。紡出原液, フズ ル, 浴間緊張比, 浸せき長などを变えて約 50 種の試料を 得た。

紡亲過程では CM 化ビスコースは良好な紀系状態を示 し，高いドラフトで紡紋でさたが，得られた織維は同条 件で作つた普通ビスコースに比較して，より低いドラフ トで作られたような系質すなわも伸度が大きく，結節強 度が高い結果孝与克た。しかしながら，普通ビスコースに 比較して特に大きく变わつたbのではない。太いデニー

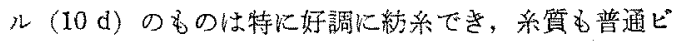
スコースのものよりよいようであのた。湿潤強度は子想 外によく，普通ピスコースに少らないが，冷アルカリに 対する溶解度が增し，洗たくに注意を要するである5。

$\mathrm{CM}$ 基を持つた㵶維を酸型にした後, 各種の金属イオ ンを 1 モル $/ l$ 含有する水溶液に浸子きし，充分イオン艾 换してから取出し，無塩水で洗浄し，風執して金属イオ 


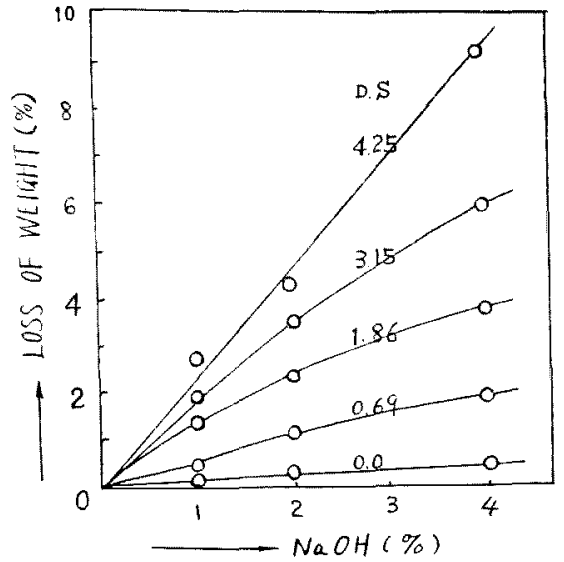

Fig. 4. Loss by solution in caustic soda at $25^{\circ} \mathrm{C}$.

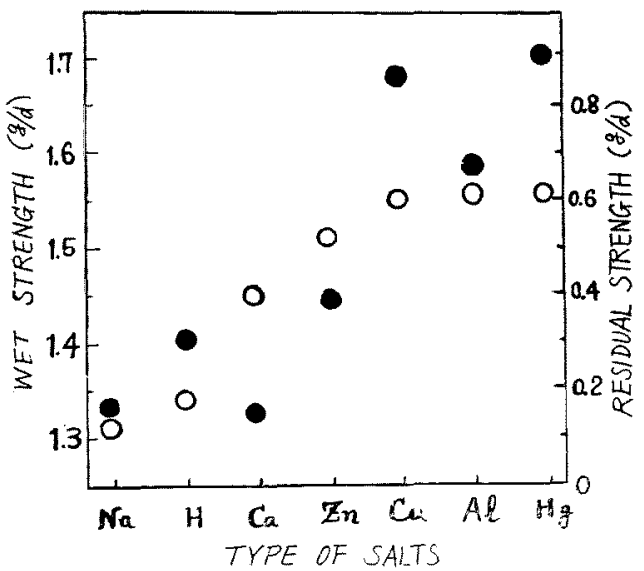

Fig. 5. Wet strength $(O)$ of various salts of carboxymethylated viscose rayon $(D . S .=4.25)$ and their residual strength (O) after burried in soil for Lmonths.

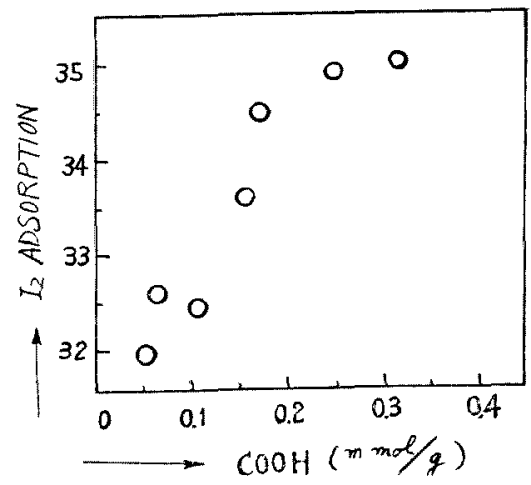

Fig. 6. Corelation between carboxyl-content (m $\mathrm{mol} / \mathrm{g}$ ) and Iodine adsorption (mol/100 glucose units) at $25^{\circ} \mathrm{C}$.
ンを含む緎維とした（程の量は灰分より確認した。）。 の系の湿潤強度を测定した結果と，同瀻維を埋没して磨

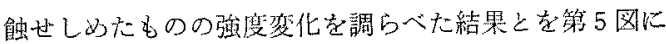
示した。銅, 水銀,アルミニウムは有効である(3d 学使用)。

$\mathrm{CM}$ 基圭含有すれば凝固状態方黑なり，䄉維中の結晶 領域は減少し、アタセシビリアイ一は増加与ると侾えら

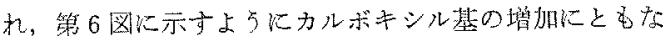
沃度吸玨量が增加している。

\section{4. 総括}

アルカリセルロース老成と平行しつつCM 化し，こ 扎を硫化，溶解，紡采して CM 化ビスコース・レーヨン を得た。この過程では普通のビスコースと此較して重大 な困鞋はなからた。CM 化されたアルセルの硫化度は低 いが，CM 基によつてアルカリ易溶性になつているの

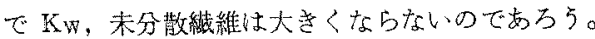

得られた纎維は普通ビスコースと大差ない機珹的性筫 を持つて和り，沃度吸着量快大き。銅，办銀，アルミ 二ウム境にしたものは游菌性を持b，湿潤強度も向上す る。

（樹脂加工性については別途に検討中である。また本 方法によるときはどスコース中の $\mathrm{Cl}^{-}$の增加を避けられ ない。徝つて工業化に際しては㵀固浴回取装置の鉛との 関係を检討しなければならないであるら。別途調整さ れたアルカり可溶性の CMC とビスコースとの混合紡亲 の㛟討死残されていることを付記する。）

発表を評可された会社当局，御指導下さつた栗山捈三 九州大学名管滁授，藤村敏一八代研究所長，実験を担当 した犬束渟・松尾和人・大橋臽夫の諸氏に感謝しむす。

文献

1) G.C.Daul, R. M. Reinhardt, J.D. Reid; Text. Res. J., 17, 554 (1947), 18, 551 (1948), 20, $657(1950), 22,787,792(1952), 23,719(1953)$

2) 同上; U.S.P. 2448153, U.S.P. 2495767 , U.S.P. 2584114.

3) R.W. Maxwell ; U.S.P. 2236544.

4) 祖父江 他 ; 工化, 57, 247 (1954)

5) A.Z. Conner, R.W. Eylen; Anal. Chem., 22. 1129 (1950)

6) A. Schwertassek ; Faserforsch. u. Textiltech. 3, 87 (1952), Melliand Textilber. 31, 764 (1950), 32, 460, 774 (1951)

7) C.E.Hessler, R. E. Power ; Text. Res. J., 24, 822 (1954) 